Original Research Article

\title{
Active surveillance of adverse drug reactions in patients with rheumatoid arthritis in a tertiary care teaching hospital
}

\author{
Nalini R. ${ }^{1 *}$, Keerthi D. ${ }^{1}$, Meenakshi B. ${ }^{1}$, Ezhil Ramya J. ${ }^{1}$, Vidhya ${ }^{2}$
}

${ }^{1}$ Department of Pharmacology,

${ }^{2}$ Department of Rheumatology,

Tirunelveli Medical College,

Tirunelveli, Tamil Nadu, India

Received: 25 July 2018

Accepted: 30 August 2018

*Correspondence to:

Dr. Nalini R.,

Email: nalluprabha@gmail.com

Copyright: () the author(s), publisher and licensee Medip Academy. This is an openaccess article distributed under the terms of the Creative Commons Attribution NonCommercial License, which permits unrestricted noncommercial use, distribution, and reproduction in any medium, provided the original work is properly cited.

\begin{abstract}
Background: Drugs used in the treatment of rheumatoid arthritis show significant toxicity and morbidity. The objective of the study was to evaluate the nature and incidence of adverse drug reaction in patients with rheumatoid arthritis on anti-rheumatic drugs and to assess the causality and severity of the documented adverse drug reactions.
\end{abstract}

Methods: The prospective observational study was done for two months in rheumatology outpatient department. All patients were interviewed for basic details, treatment history and adverse drug reactions and were recorded. Causality assessment and severity assessment of the recorded adverse drug reactions were done.

Results: About 283 patients attended the rheumatology out-patient department during the two months period out of which 57 patients had one or more adverse drug reaction. The incidence of adverse drug reaction observed in rheumatology out-patient department to anti rheumatic drug was $20.14 \%$. A total of 145 adverse drug reactions were noted in 57 patients. The most common adverse drug reaction reported was epigastric pain $(6.89 \%)$ followed by headache and dyslipidemia $(6.25 \%)$. The most common system associated with adverse drug reaction was gastrointestinal system $(29.66 \%)$ followed by central nervous system and cardiovascular system (15.86\%). Reported adverse drug reactions were assessed for causality and maximum belonged to probable (66.9\%). Severity assessment revealed that most of the adverse drug reactions were mild $(74.48 \%)$ in nature.

Conclusions: Active surveillance for adverse drug reactions to anti rheumatic drug in patients with rheumatoid arthritis will allow early detection of adverse drug reactions and timely intervention to provide maximum benefit to the patients.

Keywords: Adverse drug reaction, Corticosteroids, Disease modifying antirheumatic drugs, Rheumatoid arthritis

\section{INTRODUCTION}

Rheumatoid arthritis (RA) is a chronic progressive multi systemic autoimmune disorder characterised by inflammation of proliferating synovial membrane in joints producing swelling, pain, stiffness and joint destruction. ${ }^{1,2}$ RA has global prevalence of approximately $0.5 \%-1 \%$ and it usually affects middle aged adults, with females more than males and with a significant disability, morbidity and mortality. 2,3 The prevalence of rheumatoid arthritis in the adult Indian population is $0.75 \%$. $^{4}$
The primary aim of treatment of RA is prevention of structural damage and to improve the quality of life of the patients. ${ }^{5}$ The first line agents used in the management of patients with established rheumatoid arthritis are the disease modifying anti rheumatic drugs (DMARDs). ${ }^{6}$ DMARDs are classified into biologic and non-biologic or synthetic DMARDs. ${ }^{7}$

Non-steroidal anti-inflammatory drugs used in the treatment of rheumatoid arthritis were previously considered as the core of all rheumatoid arthritis therapy 
but now they are considered as adjunctive therapy for management of symptoms not controlled by other measures. ${ }^{8}$ Glucocorticoids are used in rheumatoid arthritis for anti-inflammatory effect and it helps to retard the disease progression and joint damage and they are mainly used to control the short term acute flare ups while waiting for the DMARDs to act. ${ }^{1,9}$

The most common toxicity due to disease modifying anti rheumatic drug, methotrexate are nausea and mucosal ulcers and the frequently occurring hepatotoxicity is in the form of hepatic enzyme elevation. ${ }^{4}$ Approximately $30 \%$ of the patients using sulfasalazine discontinue the drugs because of toxicity. The dosage of hydroxychloroquine greater than $6.4 \mathrm{mg} / \mathrm{kg} /$ day are prone for ocular toxicity than at lower dose. However, it is advisable to do ophthalmologic monitoring every 6 to 12 months. ${ }^{4}$

Drugs used in the treatment of rheumatoid arthritis show significant toxicity and leading cause for morbidity, therefore monitoring for adverse reaction is necessary for early detection of toxicity and should be documented and the patient should be informed as well. ${ }^{10}$ Hence the present study of active surveillance of adverse drug reactions (ADRs) in patients with RA on anti-rheumatic drugs is done for the early detection of adverse drug reaction, for their management and reduction of morbidity.

The aim of the study was to evaluate the nature of the adverse drug reactions and to assess the causality and severity of the documented ADRs and to identify the modes of management of ADRs in the patients on anti rheumatic drugs for rheumatoid arthritis.

\section{METHODS}

The present study was conducted in the rheumatology outpatient department of a tertiary care teaching hospital, Tirunelveli medical college in India. This study was a prospective observational study conducted for a period of two months (August 2017 to September 2017).

\section{Inclusion criteria}

All the patients of either gender diagnosed with rheumatoid arthritis attending the rheumatology outpatient department and on anti rheumatic drugs.

\section{Exclusion criteria}

No patients with rheumatoid arthritis on anti-rheumatic drugs.

The study was commenced after obtaining approval from institutional ethical committee. Written informed consent was obtained in local vernacular language from all the patients included in the study. All patients irrespective of age and gender taking treatment for rheumatoid arthritis were included in the study. Demographic details, disease details, drug history, adverse drug reaction if any were recorded. Clinical examination was done and recorded for all the patients on drugs. Laboratory examination like renal function test, liver function test, lipid profile, blood sugar and complete blood count were done and recorded.

Causality assessment of the ADRs were done using World health organisation-Uppsala monitoring centre (WHOUMC) scoring system. ${ }^{11}$ The severity assessment of the adverse drug reactions was done using modified Hartwig and Siegel scale. ${ }^{12}$ System wise distribution of ADRs were tabulated and analysed. Data obtained were statistically analysed using descriptive statistics and expressed in percentage.

\section{RESULTS}

A total of 283 patients attended the rheumatology outpatient department during the two months study period out of which 57 patients had one or more adverse drug reaction (ADR). The incidence of ADR observed in rheumatology out- patient department to anti rheumatic drug was $20.14 \%$.

In the present study, among the 283 study population 73 $(25.8 \%)$ patients were males and $210(74.2 \%)$ were females (Table 1). The mean age of the study population was 44.38 years, the mean age of the male was 45.83 years and female were 42.94 years (Table 1). The duration of the rheumatoid arthritis in the study population ranged between 4 months and 23 years.

Table 1: Demographic details.

\begin{tabular}{|ll|}
\hline Variable & Value \\
\hline Number of patients (n) & 283 \\
\hline Males (\%) & $73(25.8 \%)$ \\
\hline Females (\%) & $210(74.2 \%)$ \\
\hline Mean age of the study population in yrs & 44.38 \\
\hline Mean age & \\
\hline Male (n=73) (years) & 45.83 \\
\hline Female (n=210) (years) & 42.94 \\
\hline Number of patients with ADRs (n) (\%) & $57(20.14 \%)$ \\
\hline Males (\%) & $6(10.53 \%)$ \\
\hline Females (\%) & $51(89.47 \%)$ \\
\hline Mean age of patients with ADR \\
\hline Male (years) & 47.83 \\
\hline Female (years) & 46.94 \\
\hline
\end{tabular}

$\mathrm{n}$ is number of patients, 283 patients attended the outpatient department 57 patients developed adverse drug reaction.

In the present study, among the 57 patients with ADR, 51 $(89.47 \%)$ patients were females and $6(10.53 \%)$ patients were males (Table 1). The mean age of the male population with ADR was 47.83 years and female were 46.94 years (Table 1). The incidence of ADRs to anti rheumatic drugs were highest in the age group of $41-50$ years $(7.42 \%)$ followed by $51-60$ years $(7.07 \%)$ (Figure 1$)$.

The drugs received by the $57(20.14 \%)$ patients were combination of steroids, non-steroidal anti-inflammatory 
drugs (NSAIDs) and DMARDs in $12.01 \%$ patients, steroids and DMARDs in $8.13 \%$ of patients (Table 2).

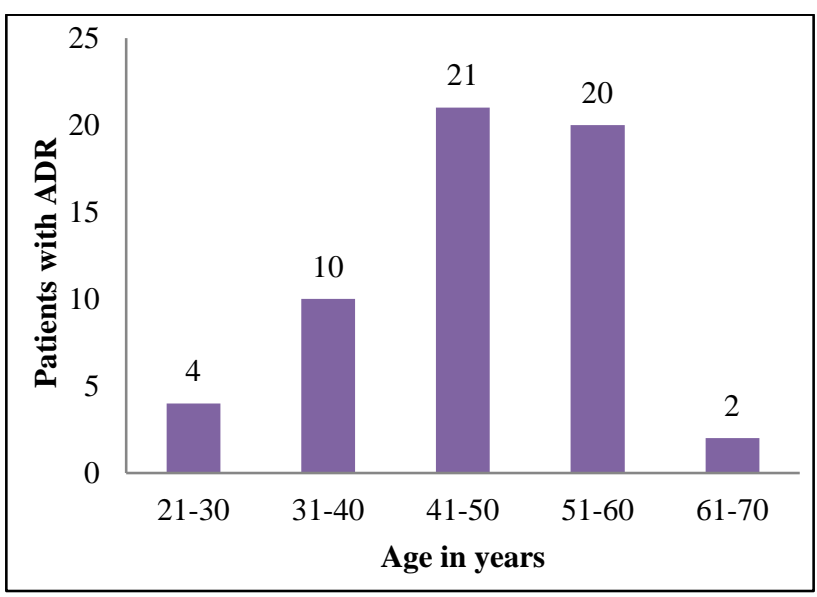

ADR adverse drug reaction

Figure 1: Age distribution of patients with ADR.

Table 2: Classes of anti-rheumatic drugs.

\begin{tabular}{|lll|}
\hline Combination of drugs & $\begin{array}{l}\text { Frequency } \\
(\mathbf{n})\end{array}$ & $\begin{array}{l}\text { Percentage } \\
(\boldsymbol{\%})\end{array}$ \\
\hline $\begin{array}{l}\text { Steroids, NSAIDs and } \\
\text { DMARDs }\end{array}$ & 34 & 12.01 \\
\hline Steroids and DMARDs & 23 & 8.13 \\
\hline Total & 57 & 20.14 \\
\hline
\end{tabular}

NSAIDs-non-steroidal anti-inflammatory drugs, DMARDsdisease modifying anti rheumatic drugs, $n$ is number of patients

Table 3: Pattern of DMARDs.

\begin{tabular}{|lll|}
\hline Drugs & $\begin{array}{l}\text { Frequency } \\
\text { (n) }\end{array}$ & $\begin{array}{l}\text { Percentage } \\
(\%)\end{array}$ \\
\hline Monotherapy & 12 & 4.24 \\
\hline Hydroxychloroquine & 11 & 3.89 \\
\hline Methotrexate & 25 & 8.83 \\
\hline Combination therapy & 2 & 0.71 \\
\hline $\begin{array}{l}\text { Methotrexate and } \\
\text { Hydroxychloroquine }\end{array}$ & 1 & 0.35 \\
\hline $\begin{array}{l}\text { Hydroxychloroquine and } \\
\text { certolizumab }\end{array}$ & 2 & 0.71 \\
\hline $\begin{array}{l}\text { Hydroxychloroquine and } \\
\text { Sulphasalazine }\end{array}$ & 1 & \\
\hline $\begin{array}{l}\text { Hydroxychloroquine, } \\
\text { Methotrexate and } \\
\text { Sulphasalazine }\end{array}$ & 20.14 \\
\hline $\begin{array}{l}\text { Hydroxychloroquine, } \\
\text { Methotrexate and } \\
\text { Rituximab }\end{array}$ & 1 & 0.35 \\
\hline $\begin{array}{l}\text { Hydroxychloroquine, } \\
\text { Methotrexate and } \\
\text { Tocilizumab }\end{array}$ & 57 & 0.71 \\
\hline $\begin{array}{l}\text { Hydroxychloroquine, } \\
\text { Methotrexate and } \\
\text { certolizumab }\end{array}$ & 2 & 25 \\
\hline \begin{tabular}{l} 
Total \\
\hline
\end{tabular} & 1 & \\
\hline
\end{tabular}

DMARDs disease modifying anti rheumatic drugs, $\mathrm{n}$ is number of patients.

Table 4: Adverse drug reactions produced by anti rheumatic drugs.

\begin{tabular}{|c|c|c|c|}
\hline $\begin{array}{l}\text { Adverse drug } \\
\text { reaction }\end{array}$ & $\begin{array}{l}\text { No. of } \\
\text { ADR } \\
(n=283)\end{array}$ & $\begin{array}{l}\text { Percentage } \\
(\%)\end{array}$ & $\begin{array}{l}\text { Causative } \\
\text { drug }\end{array}$ \\
\hline \multicolumn{4}{|c|}{ Gastrointestinal system } \\
\hline Epigastric pain & 10 & 6.89 & $\begin{array}{l}\text { Steroid, } \\
\text { NSAIDs, } \\
\text { DMARDs }\end{array}$ \\
\hline Vomiting & 8 & 5.52 & $\begin{array}{l}\text { Steroid, } \\
\text { NSAIDS }\end{array}$ \\
\hline Nausea & 6 & 4.14 & $\begin{array}{l}\text { Steroid, } \\
\text { NSAIDs, } \\
\text { DMARDs }\end{array}$ \\
\hline Dyspepsia & 5 & 3.45 & $\begin{array}{l}\text { Steroid, } \\
\text { NSAIDs }\end{array}$ \\
\hline Apthous ulcer & 5 & 3.45 & $\begin{array}{l}\text { DMARDs, } \\
\text { NSAIDs }\end{array}$ \\
\hline $\begin{array}{l}\text { Elevated liver } \\
\text { enzymes }\end{array}$ & 5 & 3.45 & DMARDs \\
\hline Mucositis & 2 & 1.38 & DMARDs \\
\hline Diarrhoea & 2 & 1.38 & $\begin{array}{l}\text { NSAIDs, } \\
\text { DMARDs }\end{array}$ \\
\hline \multicolumn{4}{|c|}{ Central nervous system } \\
\hline Headache & 9 & 6.21 & $\begin{array}{l}\text { Steroid, } \\
\text { NSAIDs }\end{array}$ \\
\hline Insomnia & 7 & 4.83 & Steroid \\
\hline Dizziness & 5 & 3.45 & Steroid \\
\hline Infection & 2 & 1.38 & $\begin{array}{l}\text { Steroid, } \\
\text { DMARDs }\end{array}$ \\
\hline \multicolumn{4}{|l|}{ Cardiovascular system } \\
\hline Dyslipidemia & 9 & 6.21 & Steroid \\
\hline Hypertension & 8 & 5.52 & Steroid \\
\hline Palpitation & 6 & 4.14 & Steroid \\
\hline \multicolumn{4}{|l|}{ Endocrine system } \\
\hline Hyperglycemia & 7 & 4.83 & Steroid \\
\hline Cushings syndrome & 8 & 5.52 & Steroid \\
\hline \multicolumn{4}{|l|}{ Dermatology } \\
\hline Skin rash & 7 & 4.83 & DMARDs \\
\hline Alopecia & 5 & 3.45 & DMARDs \\
\hline Hyperpigmentation & 5 & 3.45 & DMARDs \\
\hline \multicolumn{4}{|l|}{ Ophthalmology } \\
\hline Blurring of vision & 7 & 4.83 & DMARDs \\
\hline Presenile cataract & 1 & 0.68 & Steroid \\
\hline \multicolumn{4}{|l|}{ Hematology } \\
\hline Anemia & 3 & 2.07 & DMARDs \\
\hline Leucopenia & 3 & 2.07 & DMARDs \\
\hline Thrombocytopenia & 2 & 1.38 & DMARDs \\
\hline \multicolumn{4}{|c|}{ Gentitourinary system } \\
\hline $\begin{array}{l}\text { Urinary tract } \\
\text { infection }\end{array}$ & 5 & 3.45 & $\begin{array}{l}\text { Steroid, } \\
\text { DMARDs }\end{array}$ \\
\hline \multicolumn{4}{|l|}{ Respiratory system } \\
\hline Exacerbation of TB & 2 & 1.38 & $\begin{array}{l}\text { Steroid, } \\
\text { DMARDs }\end{array}$ \\
\hline $\begin{array}{l}\text { Asthma } \\
\text { exacerbation }\end{array}$ & 1 & 0.68 & NSAIDs \\
\hline
\end{tabular}


The pattern of drug therapy of DMARDs in patients with ADR were, $12(4.24 \%)$ patients received monotherapy hydroxychloroquine, $11(3.89 \%)$ patients received monotherapy methotrexate, $25(8.83 \%)$ patients received combination of methotrexate and hydroxychloroquine, 2 $(0.71 \%)$ patients received combination of hydroxychloroquine and certolizumab, hydroxychloroquine, methotrexate and certolizumab, and hydroxychloroquine, methotrexate and sulphasalazine, and finally $1(0.35 \%)$ patient received combination of hydroxychloroquine, methotrexate and tocilizumab, hydroxychloroquine, methotrexate and rituximab and hydroxychloroquine and sulphasalazine (Table 3).

Table 5: System associated with adverse drug reactions.

\begin{tabular}{|lll|}
\hline System & $\begin{array}{l}\text { Frequency } \\
(\mathbf{n})\end{array}$ & $\begin{array}{l}\text { Percentage } \\
(\%)\end{array}$ \\
\hline Gastro intestinal system & 43 & 29.66 \\
\hline Central nervous system & 23 & 15.86 \\
\hline Cardiovascular system & 23 & 15.86 \\
\hline Dermatology & 17 & 11.72 \\
\hline Endocrinology & 15 & 10.34 \\
\hline Ophthalmology & 8 & 5.52 \\
\hline Haematology & 8 & 5.52 \\
\hline Genitourinary system & 5 & 3.45 \\
\hline Respiratory system & 3 & 2.07 \\
\hline
\end{tabular}

$\mathrm{n}$ is number of patients.

A total of 145 adverse drug reactions were noted in 57 patients. The most common ADR reported was epigastric pain $(6.89 \%)$ followed by headache and dyslipidemia (6.21\%). The least common ADRs were asthma exacerbation and presenile cataract $(0.68 \%)$ followed by diarrhoea, mucositis, infection and thrombocytopenia (1.38\%) (Table 4).

Table 6: WHO UMC causality assessment of adverse drug reactions.

\begin{tabular}{|lll|}
\hline Causality & Frequency (n) & Percentage (\%) \\
\hline Probable & 97 & 66.9 \\
\hline Possible & 48 & 33.1 \\
\hline Certain & NIL & NIL \\
\hline
\end{tabular}

$\mathrm{n}$ is number of patients, WHO UMC- World Health Organisation Uppsala Monitoring Centre.

The most common system associated with ADR was gastrointestinal system $(29.66 \%)$ followed by central nervous system and cardiovascular system (15.86\%). The least common system associated with ADR was respiratory system $(2.07 \%)$ followed by genitourinary system $(3.45 \%)$ (Table 5).

As per WHO UMC causality assessment of ADRs associated with anti rheumatic drugs, 97 (66.9\%) ADRs were termed probable, 48 (33.1\%) ADRs were categorised as possible and none of the ADRs were termed certain (Table 6).

The severities of the reported ADRs were assessed by modified Hartwig and Siegel scale. 108 (74.48\%) ADRs were termed mild, $28(19.31 \%)$ ADRs were termed moderate and $9(6.21 \%)$ ADRs were termed severe (Table 7). Regarding the modes of management of the ADRs, the drug doses were reduced for $62(42.76 \%)$ ADRs, the same treatment were continued for 42 (28.97\%) ADRs, symptomatic treatment for the adverse reaction was given for $23(15.86 \%)$ ADRs and the drug causing adverse reaction was withdrawn for 15 (12.41\%) ADRs (Table 8).

Table 7: Severity of adverse drug reactions.

\begin{tabular}{|lll|}
\hline Severity & Frequency $(\mathbf{n})$ & Percentage $(\%)$ \\
\hline Mild & 108 & 74.48 \\
\hline Moderate & 28 & 19.31 \\
\hline Severe & 9 & 6.21 \\
\hline
\end{tabular}

$\mathrm{n}$ is number of patients.

Table 8: Modes of management of ADRs.

\begin{tabular}{|lll|}
\hline Treatment & $\begin{array}{l}\text { No. of ADRs } \\
\text { (n) }\end{array}$ & $\begin{array}{l}\text { Percentage } \\
(\%)\end{array}$ \\
\hline Dose reduced & 62 & 42.76 \\
\hline Continued the same & 42 & 28.97 \\
\hline Symptomatic treatment & 23 & 15.86 \\
\hline Drug withdrawn & 18 & 12.41 \\
\hline
\end{tabular}

$\mathrm{n}$ is number of patients, ADRs adverse drug reactions.

\section{DISCUSSION}

Rheumatoid arthritis is a chronic disease that causes disability, morbidity and increased mortality therefore management of rheumatoid arthritis should focus on reducing the complications of the disease with diminution of symptoms and disabilities. ${ }^{13}$ The mainstay of treatment of RA is early use of small molecule DMARDs in order to improve the clinical outcome. ${ }^{14}$ Oral corticosteroids are viable and most widely used therapeutic option for rapidly and effectively managing RA symptoms. ${ }^{14,15}$ Increase in dose escalation, use of additional DMARDs or use of biologicals is necessary if there is partial or non response to DMARDs. ${ }^{14}$ Methotrexate is considered as the first DMARD of choice in the management of RA. Methotrexate is active in management of RA at lower doses than those needed in cancer chemotherapy. ${ }^{4}$ Methotrexate is considered to be the most tolerable in long term therapies. ${ }^{16}$ However chronic use of steroids, NSAIDs and DMARDs, both biological and non biologicals, used for the management of RA can increase the type and frequency of adverse reactions. Regular monitoring of antirheumatic drug therapy is the key to minimize drug toxicity. ${ }^{16}$

The prevalence of RA is more in females than in males, the reason for this over presentation of women are not clear but $\mathrm{x}$ linked genetic factors and hormonal aspects are likely to 
be involved. ${ }^{17}$ In the present study, $20.14 \%$ patients were reported to have atleast one ADR while on anti rheumatoid drugs. A retrospective study conducted by Alba $\mathrm{M}$ et al, showed $30.7 \%$ patients had at least one ADR when taking DMARDs. The range of ADR reported by other authors were $19.0 \%$ to $32.8 \% .^{13}$

The adverse effects related to corticosteroids in the present study are epigastric pain, headache, dyslipidemia, hypertension, nausea, vomiting, dyspepsia, hyperglycemia, cushings syndrome and presenile cataract. The ADR in the study conducted by Alba $\mathrm{M}$ et al, were weight gain, increased blood pressure and gastrointestinal events and the most common being osteoporosis and cushings disease. ${ }^{13}$

The adverse effect related to DMARDs in the present study are nausea, vomiting, diarrhoea, mucostis, apthous ulcer, elevated liver enzymes, skin rash, hyperpigmentation, alopecia, blurring of vision, anemia, leucopenia, thrombocytopenia and infection. In the study conducted by Singh $\mathrm{P}$ et al, the ADRs produced by methotrexate were stomach pain, nausea, diarrhoea, leucopenia, anemia, and thrombocytopenia. The ADRs of hydroxychloroquine were nausea, stomach pain, stomach cramps, diarrhoea, blurred vision, hyperpigmentation. ${ }^{4}$ In the present study 7 patients developed blurring of vision but in study conducted by Singh $\mathrm{P}$ et al, showed 2 patients with blurring of vision. Blurred vision occurs in up to $3 \%$ of patients due to corneal deposits and may be reversible and the retinal deposition of hydroxychloroquine is a concern because this is more common in older patients on longer-term treatment and is irreversible and may worsen with time. ${ }^{4}$

In the present study, 5 patients developed hyperpigmentation of the skin but in study conducted by Singh $\mathrm{P}$ et al, showed that 7 patients developed hyperpigmentation. Hydroxychloroquine induced pigmentation is not a rare adverse effect. Use of antimalarials like quinacrine, chloroquine, and hydroxychloroquine can induce tissue pigmentation in a variety of organs, including skin, joint tissue, trachea, and cartilage in the nose and ears. Skin biopsies performed on patients showed that the median concentration of iron was significantly higher in biopsy specimens of pigmented lesions compared with normal skin. So, it was hypothesis that hydroxychloroquine induced pigmentation is secondary to ecchymosis or bruising. Studies have found an association of elevated blood hydroxychloroquine concentration and gastrointestinal adverse events. ${ }^{4}$

The most common ADR associated with sulphasalazine are blood disorders. ${ }^{13}$ Majority of side-effects with sulphasalazine occur early, and on cessation of therapy most of the side effects reverse completely. Therefore, frequent monitoring is necessary in the first six months. No cumulative or unexpected long term toxicity is known. ${ }^{4}$

In the present study drug was withdrawn for $18 \mathrm{ADR}$, they were maculopathy due to dihydroxychloroquine, elevated liver enzymes due to methotrexate, exacerbation of tuberculosis, central nervous system infection due to steroids and DMARDs and thrombocytopenia due to DMARDs. In a study conducted by Machodo et al, patients treated with non-biological DMARDs did not require drug withdrawal as often as those taking biological DMARDs. ${ }^{13}$ The assessment of the severity scoring of the ADR in the present study showed that $74.48 \%$ were mild in nature, $19.31 \%$ were moderate and $6.21 \%$ were severe in nature. In a study conducted by Sing $\mathrm{P}$ et al, no severe ADRs according to modified Harwig and Siegel scale were observed. $^{4}$

The drugs used in treatment of RA pose distinct problems, most of which are transitory, immunosuppressive medications increase the risk of serious infections, and glucocorticoids predispose to osteoporosis, hypertension, diabetes mellitus, and cataract. ${ }^{4,15}$ However, adverse effect associated with low dose glucocorticoid are modest than with high-dose glucocorticoid. ${ }^{4,18}$ Chronic use of glucocorticoid doubles the already increased risk of osteoporosis in RA and low dose regimen rarely induces psychosis associated with glucocorticoids. ${ }^{18}$

At present, there is no curative therapy available for the management of RA but the current treatment of RA should remove the inflammatory symptoms rapidly, safely and prevent permanent damage and should be financially available to all patients. ${ }^{4}$ The limitation of the present study is that, the study is done in a small population and for short period of time and were confined to out-patient department only. As the patient was on multiple drugs there were overlapping of toxicities hence it was difficulty in identifying which drug produced the adverse reaction. Further, more similar studies are required for the recording and updating of the incidence of ADRs in patients with RA.

\section{CONCLUSION}

The most commonly used drugs in the treatment of rheumatoid arthritis are DMARDs and steroids which are commonly associated with adverse drug reactions. The ADRs reported in the present study are characteristic of these drugs. Active surveillance for adverse drug reactions to anti rheumatic drug in patients with rheumatoid arthritis allows early detection of ADRs and timely intervention to provide maximum benefit to the patients.

\section{ACKNOWLEDGEMENTS}

Authors would like to thank colleagues of the department of Pharmacology and department of Rheumatology of Tirunelveli medical college and hospital, Tirunelveli, Tamilnadu for their constant support. The authors would also like to thank the patients included in the present study.

Funding: No funding sources

Conflict of interest: None declared

Ethical approval: The study was approved by the Institutional Ethics Committee 


\section{REFERENCES}

1. Shah A, E. William St Clair. Rheumatoid arthritis. Harrison's principles of internal medicine. $19^{\text {th }} \mathrm{Ed}$. Newyork, Mc Graw Hill. 2015:2136-49.

2. Buhroo AM, Baba AN. Adverse effects of low-dose methotrexate in patients with rheumatoid arthritis. IJPMR. 2006;17(2):21-5.

3. Waserman A. Diagnosis and management of rheumatoid arthritis. Am Fam Physician. 2011;84(11):1245-52.

4. Singh $\mathrm{P}$, Bharat S, Bano M, Gaur S, Srivastava B. Adverse drug reaction in rheumatoid arthritis patients taking combination DMARDs. J Med Sci Clin Res. 2016;4(8):12115-24.

5. Smolen JS, Landewé R, Breedveld FC, Dougados M, Emery P, Gaujoux-Viala C, et al. EULAR recommendations for the management of rheumatoid arthritis with synthetic and biological disease modifying antirheumatic drugs. Ann Rheum Dis. 2010;69(6):964-75.

6. Singh JA, Saag KG, Bridges Jr SL, Akl EA, Bannuru RR, Sullivan MC, et al. 2015 American College of Rheumatology guideline for the treatment of rheumatoid arthritis. Arthritis Rheumatol. 2016 Jan;68(1):1-26.

7. Ahmed A. Negum, Daniel E Furst. Non-steroidal antiinflammatory drugs, disease modifying antirheumatic drugs, non-opioid analgesics and drugs used in gout. Bertram G Katzung Katzung Basic and clinical pharmacology, $14^{\text {th }}$ Ed. New York, Mc Graw Hill. 2018:649-659.

8. Ankoor Shah, E.William St. Clair. Rheumatoid arthritis. Anthony S. Fauci Harrisons Rheumatology. $3^{\text {rd }}$ Ed. Newyork, McGrawHill. 2013:87-105.

9. Bernard P. Schimmer and John W. Funder. Adrenocorticotropic hormone, Adrenal steroids and the Adrenal cortex. Goodman and Gillman's Pharmacological Basis of Therapeutics. 13 ${ }^{\text {th }}$ Ed. Newyork, NY: Mc Graw Hill. 2018:845-61.

10. Chakravarty K, McDonald H, Pullar T, Taggart A, Chalmers R, Oliver S, et al. BSR/BHPR guideline for disease-modifying anti-rheumatic drug (DMARD) therapy in consultation with the Br Assoc Dermatol. Rheumatol. 2006 Aug 28;47(6):924-5.

11. The use of the WHO-UMC system for standardized case causality assessment. Available at: http:// whoumc.org/Graphics/24734.pdf. Accessed on 12 June 2018.

12. Hartwig SC, Siegel J, Schneider PJ. Preventability and severity assessment in reporting adverse drug reactions. Am J Health Sys Pharma. 1992 Sep 1;49(9):2229-32.

13. Machado-Alba JE, Ruiz AF, Machado-Duque ME. Adverse drug reactions associated with the use of disease-modifying anti-rheumatic drugs in patients with rheumatoid arthritis. Rev Panam Salud Publica. 2014;36(6):396-401.

14. Alastair Innes J. Rheumatology and bone disease. Davidson's Essentials of Medicine. Elsevier. 2nd ed. 2016:561-604.

15. Haraoui B, Jovaisas A, Bensen WG, et al. Use of corticosteroids in patients with rheumatoid arthritis treated with infliximab: treatment implications based on a real-world Canadian population. RMD 2015. Available at: http://dx.doi.org/10.1136/rmdopen. Accessed on 2 July 2018.

16. Al-Malaq HM, Al-Arfaj HF, Al-Arfaj AS. Adverse drug reactions caused by methotrexate in Saudi population. Saudi Pharmaceut J. 2012;20(4):301-5.

17. van Vollenhoven RF. Sex differences in rheumatoid arthritis: more than meets the eye. BMC Medicine. 2009 Dec;7(1): 12 .

18. Da Silva JA, Jacobs JW, Kirwan JR, Boers M, Saag KG, Inês LB, et al. Safety of low dose glucocorticoid treatment in rheumatoid arthritis: published evidence and prospective trial data. Ann Rheumatic Dis. 2006 Mar 1;65(3):285-93.

Cite this article as: Nalini R, Keerthi D, Meenakshi B, Ramya EJ, Vidhya. Active surveillance of adverse drug reactions in patients with rheumatoid arthritis in a tertiary care teaching hospital. Int $\mathrm{J}$ Basic Clin Pharmacol 2018;7:1981-6. 